\title{
Identifying genes that cause disease: HLA-B27, the paradigm, the promise, the perplexity
}

Medicine is entering an era that will be completely reshaped by the ability to identify genes that either cause or control the susceptibility to disease. Virtually all diseases including atherosclerosis, cancers, and infections have a genetic component. As the effort to sequence the human genome rapidly advances, progress has been made in identifying susceptibility loci for many illnesses. Some diseases like retinoblastoma and certain retinal dystrophies can result from the malfunction of a single gene. Most diseases, however, including age related cataract, glaucoma, ${ }^{12}$ and macular degeneration ${ }^{3}$ are undoubtedly multigenic. The identification of a susceptibility gene opens a Pandora's box; locating a susceptibility locus is only the first step toward unravelling the mystery of disease causation. In this regard, the tale of the HLA-B27 gene might be an instructive paradigm.

HLA (human leucocyte antigen) gene products are cell surface glycoproteins that are widely distributed on many cells. HLA antigens are intimately involved in the immune response. Consequently one's HLA genotype influences susceptibility to diseases that have an immunopathogenesis. There are dozens of autoimmune diseases that fit this description. Of all the HLA disease associations, perhaps the strongest is between HLA-B27 and ankylosing spondylitis. HLA-B27 increases one's risk of developing ankylosing spondylitis by $10000 \%$, and also greatly affects the likelihood that one might develop either a reactive arthritis or the sudden onset of a unilateral iritis. The effect of HLA-B27 on susceptibility to spondyloarthritis was reported in $1973 .^{4-6}$ We know the antigen presentation function of HLA-B27. We know the three dimensional structure of HLA-B27. We know the cellular distribution of HLA-B27. We do not know the mechanism by which HLA-B27 influences disease susceptibility.

Because of its role in immune responses, a plausible hypothesis is that HLA-B27 controls the immunity to a specific antigen that triggers spondyloarthritis. To date, such an antigen has not been identified. Since the infections that trigger reactive arthritis are quite diverse, ranging from Chlamydia to Shigella, it seems remote that a single antigen will be common yet specific for arthritogenic bacteria. A plasmid encoded antigen that may serve this function has been proposed. ${ }^{7}$ Some suggest that the actual susceptibility gene is not HLA-B27, but another gene located very close to it on the sixth chromosome. However, transgenic rats expressing human HLA-B27 develop a multisystem disease with remarkable similarity to spondyloarthritis. ${ }^{8}$ In addition to this rat model, HLA-B27 transgenic mice may also develop inflammatory arthritis. ${ }^{9}$ These observations strongly support the concept that HLA-B27 itself is the disease susceptibility marker.

A growing list of observations suggest that HLA-B27 alters the host response to Gram negative bacteria. For example, the transgenic rats that develop spondyloarthropathy stay much healthier if raised in a germfree environment such that their bowels are not colonised by enteric bacteria. As noted above, Gram negative infections or Chlamydia, which has endotoxin-like activity, trigger reactive arthritis. Endotoxin, which is the major outer cell wall constituent of Gram negative bacteria, causes a sudden onset anterior uveitis after a footpad injection in rats ${ }^{10}$ or mice. However, bacterial components other than endotoxin may be involved. A protein database search shows that HLA-B27 is unique among HLA alleles in that it shares sequence homologies of six amino acids in length with an array of Gram negative bacterially derived proteins. ${ }^{11}$ Monoclonal antibodies to HLA-B27 can cross react to Gram negative microbes, and monoclonal antibodies to certain Gram negative bacteria cross react with HLA-B27. ${ }^{12}{ }^{13}$

Why should HLA-B27 influence the body's response to Gram negative bacteria? The intracellular half life of Gram negative bacteria is prolonged in cells expressing HLA-B27. ${ }^{14}{ }^{15}$ In addition, bacterial invasion differentially affects post-transcriptional processing of the HLA-B27 pre-mRNA. ${ }^{16}$ More recently, Ikawa and colleagues found that cellular expression of HLA-B27 affects early signal transduction events at the $\mathrm{mRNA}$ level in response to bacterial invasion. ${ }^{17}$ Our preferred hypothesis is that HLA-B27 promotes the persistence of bacterial components, perhaps because of mimicry between HLA-B27 and Gram negative bacteria. The altered processing of Gram negative bacteria allows proteins or lipopolysaccharide derived from these bacteria to be more phlogistic. For example, by persisting in joint and iris these antigens are more likely to trigger an immune mediated disease. Several studies have identified bacterial antigens within the joints of patients with HLA-B27 associated arthritis, ${ }^{18}{ }^{19}$ but this does not prove a pathogenic effect nor does it determine if HLA-B27 has contributed to the antigen's presence. Alternatively, in HLA-B27 positive individuals endotoxin could preferentially act as a gatekeeper, promoting the deposition of foreign antigen in iris and synovium by its indirect effect of vascular permeability and endothelial adhesion.

The HLA-B27 story should be taken as an object lesson for scientists performing genetic mapping. In HLA-B27, 25 years ago medical science identified a gene that has a profound effect on the development of eye and joint disease. In glaucoma, cataract, and macular degeneration, it seems unlikely that a single gene will have such a marked effect on disease susceptibility. HLA-B27 typing may contribute to diagnosis of a specific subset of patients with iritis, but its promise as an aid to clarifying pathogenesis has been elusive. While embracing the rush to identify the genetic factors that control susceptibility to a host of ocular diseases, we need to recognise that the identification of a susceptibility gene is a tool but not the final destination.

This work was supported by National Eye Institute grants, EY 06484, EY 06477, and EY 06765.

TAMMY M MARTIN JAMES T ROSENBAUM

Oregon Health Sciences University, Casey Eye Institute, 3375 SW Terwilliger Blvd, Portland, OR 97201, USA

1 Wirtz MK, Samples JR, Kramer PL, et al. Mapping a gene for adult-onset primary open-angle glaucoma to chromosome 3q. Am f Hum Genet primary open-ang

2 Stone EM, Fingert JH, Alward WLM, et al. Identification of a gene that causes primary open angle glaucoma. Science 1997;275:668-670. 
3 Klein ML, Schultz DW, Edwards A, et al. Age-related macular degeneration: clinical features in a large family and linkage to chromosome 1q. Arch Ophthalmol 1998;116:1082-8.

4 Brewerton DA, Caffrey M, Nicholls A, et al. Acute anterior uveiti and HL-A 27. Lancet 1973;2:994-6.

5 Schlosstein LP, Terasaki PI, Bluestone R, et al. High association of an HLA antigen, W27, with ankylosing spondylitis. N Engl F Med 1973;288:704-6.

6 Caffrey MFP, James DCO. Human lymphocyte antigen association in ankylosing spondylitis. Nature 1973;242:121.

7 Stieglitz H, Fosmire S, Lipsky P. Identification of a 2-Md plasmid from Shigella flexneri associated with reactive arthritis. Arthritis Rheum 1989;32: 937-46.

8 Hammer RE, Maika SD, Richardson JA, et al. Spontaneous inflammatory disease in transgenic rats expressing HLA-B27 and human $\beta_{2} \mathrm{~m}$ : an animal model of HLA-B27-associated human disorders. Cell 1990;63:1099-112.

9 Khare SD, Luthra HS, David CS. Spontaneous inflammatory arthritis in HLA-B27 transgenic mice lacking $\beta_{2}$-microglobulin: a model of human spondyloarthropathies. $\mathcal{F}$ Exp Med 1995;182:1153-8.

10 Rosenbaum JT, McDevitt HO, Guss RB, et al. Endotoxin-induced uveitis in rats as a model for human disease. Nature 1980;286:611-13.

11 Scofield RH, Warren WL, Koelsch G, et al. A hypothesis for the HLA-B27 immune dysregulation in spondyloarthropathy: contributions from enteric organisms, B27 structure, peptides bound by B27, and convergent evolution. Proc Natl Acad Sci USA 1993;90:9330-4.
12 Kono DH, Ogasawara M, Effros RB, et al. Ye-1, a monoclonal antibody that cross-reacts with HLA-B27 lymphoblastoid cell lines and an arthritis causing bacteria. Clin Exp Immunol 1985;61:503-8.

13 Ren MN, Zhang JJ, Nakayama A, et al. Reactivity between monoclonal antiHLA-B27 antibodies and bacterial components: is there a consensus of findings? Rheumatol Int 1989;9:219-21.

14 Virtala M, Kirveskari J, Granfors K. HLA-B27 modulates the survival of Salmonella enteritidis in transfected L cells, possibly by impaired nitric Salmonella enteritidis in transfected $\mathrm{L}$ cells, poss

15 Laitio P, Virtala M, Salmi M, et al. HLA-B27 modulates intracellular survival of Salmonella enteritidis in human monocytic cells. Eur f Immunol 1997;27:1331-8

16 Huang $\mathrm{F}$, Yamaguchi A, Tsuchiya $\mathrm{N}$, et al. Induction of alternative splicing of HLA-B27 by bacterial invasion. Arthritis Rheum 1997;40:694-703.

17 Ikawa T, Ikeda M, Yamaguchi A, et al. Expression of arthritis-causing HLAB27 on Hela cells promotes induction of c-fos in response to in vitro invasion by Salmonella typhimurium. F Clin Invest 1998;101:263-72.

18 Granfors K, Jalkanen S, von Essen R, et al. Yersinia antigens in synovial-fluid cells from patients with reactive arthritis. N Engl f Med 1989;320:216-21.

19 Granfors K, Jalkanen S, Lindberg AA, et al. Salmonella lipopolysaccharide in synovial cells from patients with reactive arthritis. Lancet 1990;335:685- 